\title{
PROTECTING TRADITIONAL BALINESE WEAVING TROUGH COPYRIGHT LAW : IS IT APPROPRIATE?
}

\author{
Ni Ketut Supasti Dharmawan ${ }^{1 *}$ \\ arasswk@yahoo.com
}

\begin{abstract}
As part of traditional cultural expressions (TCEs), traditional weaving including "Traditional Balinese weaving" may be appropriately protected based on article 38 (1) Law No. 28 of 2014 concerning Indonesian Copyright Law. However, the new Indonesian copyright law seem unclearly protect traditional weaving expression as it is. As WIPO, in international level, protects traditional knowledge, the previous Indonesian copyright law (Law No. 19 of 2002) relatively clearly provides a legal basis to protect traditional weaving, especially when a foreigner uses traditional expression works for comercial purposes, the law empasizes that users should get a license from the state. Meanwhile, the new law is silent for a similar discourse. Therefore, the appropriate protection for traditional weaving through copyright regime is still called into question. The sui generis law, both in international and national levels, is espected to provide a legal basis protecting TCEs. Unfortunatly, it is still in the form of a bill until now in Indonesia. By understanding this phenomenon, some grounds to protect TCEs including traditional Balinese weaving can be considered such as human rights approach for traditional cultural community as well as the intangible cultural harritage approaches from UNESCO schema. In addition, sui-generis model provisions as well as inventorying and documenting can be considered as an appropriate way to prove and to preserve, safeguard, maintain, and protect traditional weaving including traditional Balinese weaving, although there are still challenges because a traditional motive of Balinese weaving is easily produced as an industrial fabric material through modern technology.
\end{abstract}

Keywords : Traditional Balinese Weaving, Traditional Culture Expressions, Copyright Law, Intangible Culture Heritage, Sui-Generis Model Provisions

\footnotetext{
${ }^{1}$ Ni Ketut Supasti Dharmawan, Lecturer at the Faculty of Law Udayana University, Bali, Indonesia. We express our gratitude to I Nyoman Udayana, Ph.D, the Head of Udayana University Language Laboratory for the proofreading.
} 


\section{Introduction}

Currently, in Indonesia, Traditional Cultural Expressions (TCEs) under the World Intellectual Property Organization (WIPO) are also called "expressions of folklore" ${ }^{2}$. With regard to Indonesian intellectual property laws, they are protected under Article 38 of the Law No. 28 of 2014 concerning Copyright. Unfortunately, Indonesian Copyrights Law does not provide specific protection for traditional weaving as part of the TCEs. Although indigenous communities belong to the entire islands of Indonesia, they preserve and develop their respective traditional weaving that it passed down from generation to generation, including the traditional Balinese weaving, which is known as "Tenun Endek." As required by TRIPs Agreement, of which Indonesia is a member, the Indonesian Copyright Law tends to protect art and literary creative works produced on an individual basis, as stipulated under Article 40 of the Indonesian Copyrights Law. It is much to be desired that this law only provides protection to communal creation works in general contexts as mentioned previously under Article 38 as well as Article 40 (1) letter o. and q.

The legal protection of Traditional Cultural Expressions in many academic forums both internationally and nationally including in Indonesia are still becoming hot issues. Most of the scholars emphasize Intellectual Property Laws regime does not properly protect the works of TCEs or folklore because of the different communal

\footnotetext{
${ }^{2}$ The WIPO mentioned that Traditional Cultural Expressions (TCEs) also called "Expression of Folklore" with its characteristic: may be considered as the forms in which traditional culture is expressed, form part of the identity and heritage of traditional or indigenous community, are passed down from generation to generation. TCEs are integral to the cultural and social identities of indigenous and local communities, they embody know-how and skills, and they transmit core values and beliefs. See WIPO, Traditional Cultural Expression, http://www.wipo.int/tk/en/folklore/ , accessed 31 August 2016

3 "Endek" is the name of Balinese traditional woven. One of the famous Balinese traditional woven is Endek woven, this traditional works woven have already existed since the kingdom era in Bali then in the 19 century it developed continually in regency of Buleleng, Bali. See Schaublin and Ramseyer, Textiles in Bali (Periplus Edition-Berkeley-Singapore, 1991).
} 
character of folklore, compared with individual works under copyrights law regime. Therefore, for further development, the creation of a Sui Generis Law protecting Traditional Knowledge and Traditional Cultural Expressions that cover the protection of folklore or TCEs is badly needed. While waiting for a new enacting as a Sui Generis Law to protect TCEs in Indonesia, it is very important to utilize the existence of Copyright Law to protect traditional cultural expressions in Indonesia including traditional Balinese weaving.

The purpose of this study is first to examine whether the copyrights law regime is adequate or appropriate to protect traditional Balinese weaving cultural expression. Furthermore, in regard to utilizing copyrights law as a tool to protect traditional cultural expressions, this article also needs to examine the mechanism used preventively to protect TCEs such as the important role of identification and documentation mechanisms as evidence for the existence of traditional creation works that it has been preserved, developed, and handed down from generation to generation among indigenous people. This study also involves other regimes pertaining to TCEs such as intangible cultural heritage, human rights, and suisgeneris related to intellectual property.

\section{International Protection of Traditional Cultural Expressions: Intangible Cultural Heritage, Human Rights, Copyright, and Sui-Generis}

Since massive efforts have been made in protecting intellectual property rights in the era of industrialization as well as globalization in the west or developed countries, in line with that phenomenon, the need for adequate protection for Traditional Knowledge (TK) and folklore or Traditional Culture Expression (TCEs) is also continually voiced by indigenous people who mainly come from developing countries which are the home of TK and TCEs. 
Based on the international debates concerning the protection and preservation of TK and TCEs, it can be recognized that the protection of TK and TCEs has been sometimes classified as a matter of intangible heritage and intellectual property. Although in the era of 1952-1972 UNESCO as a specialized agency of the United Nations system which work for educations, science, and cultural organization oscillated to determine the protection of folklore under intellectual property or intangible cultural heritage, subsequently in 1978 the UNESCO and WIPO agreed to work that UNESCO focused on the global approach, while WIPO focused on the basis of copyrights. After 1985, UNESCO had concentrated on examining folklore through cultural heritage. In 1989 the General Conference of UNESCO adopted a Recommendation of the Safeguarding of Traditional Culture and Folklore. Through this Recommendation, folklore is defined as the totality of tradition-based creations of cultural community in so far as they reflect its cultural and social identity, its standards and values are transmitted orally, by imitation or by other means. Its forms are, among others, language, literature, music, dance, games, mythology, rituals, customs, handicrafts, architecture, and other arts. ${ }^{4}$

The protection of TK and TCEs on the basis of cultural approach by UNESCO can be seen through the UNESCO Universal Declaration on Cultural Diversity 2001. Under Article 1 of the Declaration, it is very clearly regulated that cultural diversity is the common heritage of human culture which takes diverse forms across time and space. This diversity is embodied in the uniqueness and plurality of the identities of the groups and societies, making up humankind. As a source of exchange, innovation, and creativity, cultural diversity is as necessary for humankind as biodiversity is for nature. In this sense, it is the common heritage of humanity and it should be recognized and affirmed for the benefit of present and

\footnotetext{
4 Michael Blakeney, 2015, Protecting The Knowledge and Cultural Expressions of Aboriginal Peoples, University of Western Australia Law Review, Volume 39 (2), ISSN 0042-0328, p. 184185.
} 
future generations. ${ }^{5}$ Furthermore, the connection of TK and TCEs legal protection to intangible cultural heritage can be recognized through UNESCO Convention 2003 on the Safeguarding of Intangible Cultural Heritage. The Convention 2003 is aimed to safeguard the expressions, knowledge, and techniques that communities recognize as an integral part of their cultural heritage. ${ }^{6}$ This Convention also emphasizes the local, national and international levels to raise awareness concerning the importance of the intangible cultural heritage, and of ensuring mutual appreciation. The intangible culture heritage can be seen in the form of oral traditions, performing arts, local knowledge, and traditional skills. Related to that concept, in Indonesia, for example, "Traditional Balinese weaving cultural expression" can be considered as an example of traditional skills.

Article 2 of the UNESCO Convention 2003 can be used as a ground to protect TCEs. The Convention which entered into force in 2006 clearly states that the intangible cultural heritage transmitted from generation to generation in response to their environment and their interaction with nature and their history with a sense of identity and continuity. Thus, it promotes respect for cultural diversity and human creativity. For the purposes of this Convention, consideration will be given solely to such intangible cultural heritage as is compatible with existing international human rights conventions, as well as with the requirements of mutual respect among communities, groups and individuals, and of sustainable development.

\footnotetext{
${ }^{5}$ OHCHR, 1996-2016, UNESCO Universal Declaration on Cultural Diversity (2001), adopted by The General Conference, Paris, France, 2 November 2001, http://www.ohchr.org/EN/Issues/Education/Training/Compilation/Pages/19UNESCOUniversalDecl arationonCulturalDiversity(2001).aspx,

6 UNESCO, 2016, The Convention for the Safeguarding of Intangible Cultural Heritage, http://www.unesco.org/new/en/santiago/culture/intangible-heritage/convention-intangible-culturalheritage/, accessed 11 September 2016.
} 
In line with the Intangible Cultural Heritage as regulated under UNESCO Convention 2003, in order to protect TK and TCEs, it indicates that international human rights laws take an important role as a tool to protect TCEs. The relationship between protecting Intangible Cultural Heritage and Human Rights is clear; it can be seen through Article 18 of the International Covenant on Civil and Political Rights (ICCPR) in conjunction with Article 27 ICCPR to promote the sustainable development of the cultural, religious and social identity of the marginal communities, thus ultimately covering the society at large. ${ }^{7}$ Therefore, local people, national and international communities have to raise their awareness regarding the development of this law in order to protect TCEs. In addition, Article 27 of the Universal Declaration of Human Rights, as well as Article 13 and 15 of the International Covenant on Economic, Social and Cultural Rights, are also compatible to protect TK and TCEs.

Folklore or TCEs is truly a living and still developing tradition, rather than just a memory of the past. ${ }^{8}$ However, improper exploitation related to various types of folklore occurred along with the advanced development of technology, folklore is often produced as a commercial production without due respect for the cultural and economic interests of the community holder. Unfortunately, people who commercialize expression of folklore do not share what they obtain from the exploitation of folklore to the community holders who have developed and maintained the existence of folklore. Therefore, the strong initiative and need to protect folklore actually emerge from developing countries. There were several

\footnotetext{
${ }^{7}$ Federico Lenzerini, 2011, Intangible Cultural Heritage: The Living Culture of Peoples, The European Journal of International Law (EJIL) (2011), Vol. 22 No. 1, p. 115

8 The International Bureau of WIPO, 1998, The Protection of Expression of Folklore: The Attempts at International Level, Intellectual Property in Asia and the Pacific, No. 56/57 [ISSN 1014-336X, WIPO Publication No. 435(E)], p. 1, http://www.dsir.gov.in/pubs/itt/itt9903/folklore.htm, accessed 1 September 2016.
} 
efforts that had already been done to protect TK and Folklore or TCEs under Intellectual Property laws. In the very beginning, around 1960s -1990s, some developing countries attempted to regulate folklore expression under their copyrights laws such as Tunisia, Bolivia, Chile, Iran, Morocco, Algeria, Senegal, Kenya, Mali, Burundi, Colombia, Congo, Central African Republic, Ghana, Dominican Republic, Indonesia, Nigeria, and Angola. ${ }^{9}$ The legal basis protecting folklore expression under copyrights regime can be seen based on Article 15 (4) of the Stockholm Diplomatic Conference for revision of Berne Convention the 1967 and Paris (1971) Acts of the Berne Convention. The following provision is regulated under Berne Convention:

(a) In the case of unpublished works where the identity of the author is unknown, but where there is every ground to presume that he is a national of a country of the Union, it shall be a matter for legislation in that country to designate the competent authority which shall represent the author and shall be entitled to protect and enforce his rights in the countries of the Union.

(b) Countries of the Union which make such designation under the terms of this provision shall notify the Director General [of WIPO] by means of written declaration giving full information concerning the authority thus designated. The Director General at once communicates this declaration to all other countries of the Union.

Although the Bern Convention implies the possibility to protect expression folklore through Copyright, it seems that copyright law is not an appropriate means to protect folklore or TCEs. Some unique characteristics of expression folklore are not suitable and relevant with the individual notion of literary and artistic works belonging to copyright. One of the strong elements of Copyright is an individual author or so called "author-centric", otherwise expression folklore is usually recognized as a communal holder. Therefore, the notion of the author under copyright is not fulfilled by the field of folklore or TCEs.

${ }^{9}$ lbid., 
After considering that copyright regime itself is not appropriate enough to protect the expression of folklore, then "sui generis" model is promoted as a solution. In 1980 WIPO and UNESCO developed the draft of Model Provisions as a first step sui generis intellectual property system for folklore expression. In order to establish sui generis system, the Committee of Governmental Experts who worked for the Model Provisions emphasized that the provisions did not necessarily exist in the form of a separate law, they can exist as a chapter of intellectual property law dealing with preservation, promotion, as well as protection for national folklore. The words "expression" and "production" are used by Model Provisions rather than "works". It indicates that the Model Provisions are "Sui - Generis" rather than belong to copyright. ${ }^{10}$ Furthermore, in 1982 "Model Provisions for National Laws on the Protection of Expressions of Folklore against Illicit Exploitation and Other Prejudicial Actions" was adopted by WIPO and UNESCO convened in Geneva.

Actually the Model Provisions do not provide a definition concerning folklore expression; however, it clearly provides four forms of expressions with their examples. First, expressions by words (verbal) : folk tales, poetry and Riddles; Second, Expression by musical sounds (musical): folk songs and instrumental music; Third, expression by action (of the human body): folk dances, plays and artistic forms of ritual; Fourth, expression incorporated in a material object: drawing, paintings, carving, sculptures, pottery, terra-cotta, mosaic, woodwork, metal ware, jewelry, weaving, needlework, textiles, carpets, costumes, musical, instruments, as well as architectural forms. ${ }^{11}$ Related with traditional woven as part of the expression, it is clear that traditional weaving expression is protected under Model Provisions for National Laws on the Protection of Expressions of Folklore

\footnotetext{
${ }^{10}$ Ibid., p. 2.

${ }^{11}$ Ibid., p. 6
} 
against Illicit Exploitation and Other Prejudicial Actions, specifically belong to the fourth form.

In order to develop the protection of TCEs, the Model Provisions are also developed at the Regional level. For example, the Pacific Regional Framework that has been developed is based on close consultation with Forum Pacific member countries and their territories and WIPO as well as UNESCO. Part 2 of Pacific Regional Framework stipulates the meaning or definition and the holders of traditional cultural rights. The Regional Framework of Pacific Community (Part 2.6.) regulates that the traditional owners of traditional knowledge or expressions of culture are the holders of the traditional cultural right in the traditional knowledge or expressions of culture. ${ }^{12}$ As developed in Regional Pacific territory, some other regional and local initiatives such as the U.S. Indian Arts and Crafts Act of 1990 and its Enforcement Act of 2000 have developed framework to protect traditional knowledge and expressions of culture in the form of sui generis protection dealing with recognition and promotion of all the rights of Indigenous Cultural Communities. In other words, it is very important to hear an indigenous voice in order to protect indigenous knowledge and expressions of culture. ${ }^{13}$

Further development of the traditional cultural expressions also suggested that not only sui generis is related with intellectual property rights but also climate change dimensions related to cultural heritage are also needed. The climate change tends to affect the tangible and intangible cultural heritage. Therefore, in these contexts, it is relevant to adopt international human rights law concerning climate change

\footnotetext{
12 International Cultural Property Society, 2005, Regional Framework for the Protection of Traditional Knowledge and Expression of Culture, Secretariat of the Pacific Community: Model Law for the Protection of Traditional Knowledge and Expressions of Culture, International Journal of Cultural Property, 12:459-465, DOI: 10.1017/S0940739105050290, Printed in the USA, p. 460

13 Jo Recht, 2009, Hearing Indigenous Voices, Protecting Indigenous Knowledge, International Journal of Cultural Property, 16-223-254, Doi:10.1017/S0940739109990166, Printid in USA, p. 240.
} 
refugees, especially for cross-border protection. ${ }^{14}$ In line with human rights approaches, there are three dimensions related to the right to culture can be examined in order to protect traditional cultural expressions: the right to culture in national level (Constitution and Customary Law as manifestation of the right to culture), Article 15 (1) of the International Covenant on Economic Social and Cultural Rights, and the recognition of the rights of Indigenous people as regulated based on the United Nations Declaration of the Rights of Indigenous People 2007..$^{15}$

In order to widely promote protection for folklore expression in the regional as well as international level, then the Model Provisions have been adopted. In addition, WIPO with their members even would like to promote the protection of Traditional Knowledge (TK) as well as Traditional Cultural Expression (TCEs) in the form of international legal instruments in the form of treaty based or convention. Therefore international negotiations, as well as hard work, are needed to provide and promote convention-based international protection. For example, from 2000 until 2016, in order to conclude international conventions, several sessions have been conducted in drafting provisions for the protection of TCEs which embodies policy objectives and core principles of TCEs protection. Starting in 2000, WIPO members established Intergovernmental Committee on Intellectual Property and Genetic Resources, Traditional Knowledge and Folklore (IGC).

Folklore Expressions and Traditional Cultural Expressions (TCEs), are interchangeably used by IGC. It has been agreed that the protection of TCEs are not only in the form of "tangible" and "intangible" but it might involve the

\footnotetext{
${ }^{14}$ Hee-Eun Kim, 2011, Changing Climate, Changing Culture: Adding the Climate Change Dimension to the Protection of Intangible Culture Heritage, International of Cultural Property, 18-259-290, doi:10.1017/S094073911100021X, Printed in USA, p. 277

${ }^{15}$ Enyinna Sodienye Nwauche, 2010, Protecting Expression of Folklore Within the Right to Culture in Africa, PER/PELJ 2010 (13)4, Paper Presentation at Conference on Traditional Knowledge in Legal Context, the Potchefstroom Campus of the Northwest University South Africa, p.50.
} 
combination of both. Under WIPO/GRTKF/1C/8/4 Article 1 (a) of the Revised Draft Provisions for the Protection of Traditional Cultural Expression (WIPO Revised Provisions 2005), it is clearly stated that the subject matter of protection for TCEs is any form, be it tangible, intangible as well as combination thereof. WIPO/GRTKF/1C/8/4 Article 1 (a) as follows ${ }^{16}$ :

"Traditional cultural expressions" or "Expression of folklore" are any forms, whether tangible and tangible, in which traditional culture and knowledge are expressed, appear or are manifested, and comprise the following forms of expressions or combinations thereof:

(i) Verbal expressions, such as stories, epics, legends, poetry, riddles and other narratives: words, signs, names, and symbols;

(ii) Musical expressions, such as songs and instrumental music

(iii) Expressions by action, such as dances, plays, ceremonies, rituals and other performers whether or not reduced to a material form: and

(iv) Tangible expressions, such as productions of art, in particular, drawings, designs, paintings (including body-painting), carving, sculptures, pottery, terracotta, mosaic, woodwork, metalware, jewelry, baskets, needlework, textiles, glassware, costumes, handicrafts, musical instruments and architectural forms;

which are:

(aa) the products of creative intellectual activity, including individual and communal creativity;

(bb) characteristic of a community's cultural and social identity and cultural heritage;

(cc) maintained, used or developed by such community, or by individuals having the right or responsibility to do so in accordance with the customary law and practices of that community The specific choice of terms to denote the protected subject matter should be determined at the national and regional levels.

By understanding the Article (1 a.) of WIPO Revised Provisions as mentioned above, it seems that the traditional weaving as part of folklore or expression of folklore does not exist explicitly. However, by referring to the words "textiles" or

\footnotetext{
${ }^{16}$ WIPO/GRTKF/1C/8/4, 2005, Intergovernmental Committee on Intellectual Property and Genetic Resources, Traditional Knowledge and Folklore, Eighth Session, June 6 to 10, Geneva, p.11.
} 
"costumes", they may cover and provide a legal basis to protect traditional weaving creativity as part of TCEs or folklore expressions.

The WIPO IGC has continually worked to promote TCEs protection; more specifically it is supported by the need and spirit of developing countries which is the origin of TK as well as TCEs. Under the WIPO Revised Provisions, several general guiding principles are inserted in order to give a legal ground to TCEs protection. The general guiding principles that should be respected and implemented by the members are a. The principle of Responsiveness to aspirations and expectations of relevant communities; $b$. The principle of balance; c. Principle of respect for and consistency with international and regional agreements and instruments; d. The principle of Flexibility and comprehensiveness; d. The principle of Recognition of the specific nature and characteristics of cultural expression; e. The principle of Complementary with the protection of traditional knowledge; f. The principle of Respect for rights of and obligations towards indigenous peoples and other traditional communities; c. Principles of Respect for customary use and transmission of TCEs / EoF; and Principle of Effectiveness and accessibility of measures for protection. In this way, those general guiding principles seem to have covered comprehensively the need to protect TCEs both from the notion of IP protection, traditional cultural responsiveness protection and related human rights in the contexts of indigenous and traditional communities.

With the spirit to continually improve the protection of TCEs internationally, in 2009 the members agreed to develop international legal instruments as a formal treaty that binds all members and ratifies the treaty. ${ }^{17}$ WIPO IGC uses terminology "Traditional Cultural Expressions (TCEs)" rather than "Folklore". In a further development, Traditional Cultural Expressions and Folklore Expressions are

\footnotetext{
${ }^{17}$ WIPO, Traditional Knowledge and Intellectual Property-Background Brief, http://www.wipo.int/pressroom/en/briefs/tk_ip.html, accessed 1 September 2016.
} 
recognized as synonymous under the context of IGC. ${ }^{18}$ In the contexts of WIPO, IGC is a forum where WIPO member states discuss the intellectual property issues that arise in the context of access to genetic resources and benefit-sharing as well as the protection of traditional knowledge and traditional cultural expressions (the terms "traditional cultural expression and "expressions of folklore" are used interchangeably in WIPO discussion). ${ }^{19}$

Concerning the notion of TCEs, it can be also examined through WIPO Booklet No. 1. This document dealing with intellectual property, genetic resources, traditional knowledge and traditional cultural expressions describes TCEs often as the product of inter-generational and fluid social and communal creative processes, reflect and identify a community's history, cultural and social identity and values. ${ }^{20}$ TECs can be in the form of intangible, tangible or most usually a combination between the two. For example, a mixed expression of folklore would be a woven rug considered as tangible expressions that express elements of the traditional story. Otherwise, elements of the traditional story are intangible. ${ }^{21}$ The WIPO Booklet No. 1 also noted the relevancy protecting TCEs under copyright based on the compliance with elements and principles of copyright. In addition, it also possible protecting TCEs by using another type of Intellectual Property law, in this contexts industrial property law especially trademarks (such as collective marks) and geographical indications, industrial industry designs and the suppression of

\footnotetext{
18 The change in terminology from "Folklore" become "TCEs" was made because terminology "folklore" associated with the creations of lower. However, the content is still there, no change in subject matter. See Martin Girsberger and Benny Muller, 2012, International Trade in Indigenous Cultural Heritage : an Practitioners' Perspective, in Christoph B. Karolina Kuprecht and Jessica C. Lai, 2012, International Trade in Indigenous Cultural Heritage Legal and Policy Issues, Edward Elgar, UK, p. 179.

${ }_{19}$ WIPO,2016, No.2 WIPO Intergovernmental Committee on Intellectual Property and Genetic Resources, Traditional Knowledge and Folklore, Geneva 20, Switzerland, p. 1.

20 WIPO Booklet No. 1, Intellectual Property and Traditional Cultural Expression / Folklore, WIPO $\begin{array}{lccccc}\text { Publication } & \text { No. } 913 & \text { (E), } & \text { ISBN } 978-92-805-1363-9, & p\end{array}$

21 Ibid.
} 
unfair competition. ${ }^{22}$ In addition, also stated the important relationship between intellectual property protection and preservation / safeguarding in the contexts of cultural heritage. ${ }^{23}$

After understanding the subject matter, the form of protection either tangible or intangible more even combination thereof, as well as the regime of law are appropriate for TCEs, other crucial issues arise in line with TCEs protection is concerning beneficiaries. The question is who benefits from the TCEs protection, is it possible for an individual or should it be in the contexts of communal. Article 2 of the Draft Provision of WIPO/GRTKF/1C/8/4 provides that the protection of TCEs / EoF should be for the benefit of the indigenous people and traditional and other cultural communities, in whom the custody care and safeguarding the TCEs in accordance with their customary law and practices and who maintain, use or develop the TCEs as being characteristic of their cultural and social identity and cultural heritage. ${ }^{24}$ Based on the commentary and review process of the Draft Provision, it can be understood that many stakeholders emphasized that the rights belong to communal; so then the benefit should go to the communities rather than individuals. However, besides the community is the right holder, in some laws, it also gives the right to the Governing authority for the purpose of preservation and protection. Therefore, the benefit shall be applied towards national heritage, social welfare, and cultural programs. The African Group has started that principles TCEs protection should recognize the role of the State in the preservation and protection of TK and TCEs. ${ }^{25}$ Sui generis laws are also promoted in the Panama Law that Special Intellectual Regime Governing the Collective Rights of Indigenous People for the Protection and Defense of their Cultural Identity and their Traditional Knowledge of Panama, 2000. ${ }^{26}$

\footnotetext{
${ }^{22}$ Booklet No. 1, p. 10-11

${ }^{23}$ Booklet No. 1, Ibid, p.10-11

${ }^{24}$ WIPO/GRTKF/1C/8/4, 2005, Op. Cit., p. 16-19

${ }^{25} \mathrm{WIPO} / \mathrm{GRTKF} / 1 \mathrm{C} / 6 / 12$. See also WIPO/GRTKF/1C/15Prov.Para.85.

${ }^{26}$ WIPO/GRTKF/1C/8/4, 2005, Op. Cit., p. 17.
} 
Related to the benefit of rights, it can refer to Article 4 of the Draft Provision concerning "Management Rights." It is relatively flexible that the Draft Provisions adopt the national level approaches. However, with regard to the beneficiaries of protection, the existence of rights should be for the benefit of the community concerned who wishes from an agency acting on behalf of the community. Further, under WIPO/GRTKF/IC/7/15 Prov. Paras .69 and 85 also emphasize state that all nationals are the beneficiaries of TCEs protection by understanding the broad term of "cultural communities" belonging to all of the people in a particular country. Further, the Commentary of the Draft Provisions Article 2 also state that communities are made up of individuals, thus communal control and regulation of TECs finally also benefits the individuals who make up the relevant community. Therefore, individuals in practice also will benefit in accordance with customary law and practices.

\section{Indonesian Copyright Law with Regard to Protection of Traditional Balinese Weaving}

Copyright law is one of the branches of Intellectual Property Law regimes. In general intellectual property law including copyright law granting the individual right for the authors work both information and ideas which contain a commercial value. There is one of the elements of all types of Intellectual Property Rights, so called the rights to prohibit other people doing certain rights/things. For example, people are not allowed to conduct piracy, counterfeit, imitation as well for some 
cases not to conduct exploitation without the owner's permission. ${ }^{27}$ It is understood that the protection of intellectual property has rooted from the western concept which it is now emerging in the entire world. The intellectual property regime is not only protecting literary and artistic works, but also commercial and industrial properties. ${ }^{28}$ It is so called copyright and industrial property. Seemingly, in the 1950s both industrial property and copyright were first used as a reference when referring to the term 'intellectual property'. ${ }^{29}$ In international level, Article 2(viii) of the Convention Establishing the World Intellectual Property Organization (WIPO1967) is the first which defines the scope of 'intellectual property'. Further, the definition of 'intellectual property' of WIPO more or less can be seen in Trade Related Intellectual Property Rights Agreement (TRIPs Agreement) since WIPO's definition has been largely incorporated into TRIPs Agreement. ${ }^{30}$ The TRIPs Agreement is the first international agreement that requires a minimum standard for IPR protection; members should comply with the international standard, "an internationally enforceable institution through rigid treaty and a compulsory and binding dispute resolution procedure". ${ }^{31}$ TRIPs Agreement does not define intellectual property explicitly. This agreement only regulates that the term of "intellectual property" refers to all categories of intellectual property that are Copyright and Related Rights, Trademarks, Geographical Indications, Industrial Designs, Patents, Layout-Designs (Topographies) of Integrated Circuits, and Protection of Undisclosed Information. ${ }^{32}$

\footnotetext{
${ }^{27}$ William Cornish and David Llewellyn, Intellectual property: Patents, Copyright, Trade Marks and Allied Rights (Sweet \& Maxwell, London, 2003), p 6.

${ }^{28}$ Alpana Roy, 2008, 'Intellectual Property Rights: A Western Tale', (2008) 16 Asia Pac. L. Rev. at 222.

${ }^{29}$ Ibid.

${ }^{30}$ Ibid.

${ }^{31}$ Jamie Crook, 'Balancing Intellectual Property Protection with the Human Right to Health' (2005)

23 Berkeley Journal of International Law 524 at 530, http: //scholarship.law.berkeley.edu/bjil/vol23/iss3/I, accessed 26 April 2014.

${ }^{32}$ See TRIPs Agreement.
} 
As a member, Indonesia should comply with the TRIPs Agreement including transforming the international standards of TRIPs into Indonesian Copyright Law. The nature of copyright is individual protection protecting the creative works in the fields of science, art, and literature. Internationally, TRIPs Agreement related to copyright protection refers to the provisions of Article 9 Relation to the Berne Convention which basically states that Members shall comply with Articles 1 through 21 of the Berne Convention (1971) and the Appendix. ${ }^{33}$ With regard to Indonesian Copyright Law, the creators or authors obtain the rights over the works created in the form of real works of creation (fixation), not in the form of ideas; ${ }^{34}$ genuine and typical (personal) in nature; creating a work of art and literary as regulated under Article 40 of the Law No. 28 of 2014 concerning Indonesian Copyright will gain a legal protection of their works individually. By fulfilling the requirement of Copyright protection as mentioned above, therefore the Copyrights protection will apply automatically. Thus the creator has the exclusive rights to his/her creation, namely the right to publish or reproduce his/her creations or give permission for it, without prejudice to the restrictions under the legislation in force.

Creators or copyright owners who have legal protection upon their creations can either produce individual works or share them; some people create distinctive, original works of art by sharing their intellectual capabilities. The creators shall obtain legal protection in the form of the granting of Copyrights for their inspiration, high creativity, imagination, as well as skills that enable them to create an original piece of art, that has been factually realized, in which the creative works can be seen, read, or heard.

33 F Scott Kieff-Ralph Nack, International, United States and European Intellectual PropertySelected Source Materials (Aspen Publisher, New York, 2008) p 55.

\footnotetext{
${ }^{34}$ The Berne Convention emphasized that related with Copyright protection, works in general or any specified categories of works shall not be protected unless they have been fixed in some material form. Ibid., p 269. See also WIPO Copyright Treaty Article 2 and TRIPs Agreement Article 9 (2).
} 
In general, based on Article 1.1 through Article 1.4 and in conjunction with Article 40 of the Indonesian Copyright Law, the protection of copyright is comprehensible as an individual right protection and grants the author exclusive rights to copy his work. In these contexts, an author has exclusive rights that are comprised of moral rights and economic rights. The moral rights as stipulated under Article 4 of Indonesian Copyright Law is eternally inherent right to self - author/creator such as the right to change the title and subtitle of the literary works. In other words, moral rights are personal or not economic rights of authors. The concept of moral rights is based on European concept that unspeakable with the author. There are three types of moral rights: the right to be identified as the author of work, the right to object to derogatory treatment of work, and the right against the false attribution of a work. ${ }^{35}$ Meanwhile, an economic right is the exclusive rights of the author/creator or the copyright holder to gain economic benefit from his/her creation. In this context, the Copyright Act grants the author/creator exclusive right to publish the work, reproduce it in all forms, translate it, transform it, perform it, announce it, as well as communicate it to the public. Those economic rights of the creator are afforded by the Indonesian Copyright Act in line with TRIPs Agreement as well as Berne Convention. In addition, in line with the nature of Intellectual Property Law, the Indonesian Copyrights law provides a limited period of protection for the author/creator. The Copyright Act of Indonesia also affords a certain period of protection to the author or creator. For example, mostly Indonesian Copyright Law protects an author for the lifetime of the author/creation plus 70 years based on Article 58 (1) (2). ${ }^{36}$ However some of the creation works

\footnotetext{
35 Jordanna Bowman, 2011, Coping with Culture: Copyright, cultural expressions and inadequacy of protection for Maori, University of Otago, Dunedin, New Zealand, p. 12.

${ }^{36}$ Article 50 of Indonesian Copyright Law stipulate that creator is afforded protection for the lifetime plus 70 years for his/her creation works as follows: a. books, pamphlets, and all other written works; b. speeches, lectures, speeches, and other similar Creation; c. props made for the purposes of education and science; $d$. songs or music with or without text; e. drama, musicals, dance, choreography, puppet shows, pantomimes; f. works of art in all forms such as painting, drawing, sculpture, calligraphy, sculpture, sculpture, collage; g. works of architecture; h. maps; and i. art batik artwork or other motives.
} 
owned or held by the legal entity shall be valid 50 (fifty) years since the announcement was first made, it can be seen through Article 58 (3). By exploring the nature of copyright, Indonesian Copyright Law contains some elements of copyright such as originality, economic rights, moral rights, authorship, as well as the duration of protection.

Indonesian Copyright Law actually protects copyrighted works on an individual legal basis as referred to in TRIPs Agreement. It also provides legal protection for the traditional cultural expressions as they are continually developed by WIPO IGC. Article 38 (1) of Law No. 28 of 2014 clearly states that copyright on traditional cultural expressions is held by the State. In order to protect the TCEs, the State shall inventory, maintain, and preserve TCEs. Furthermore, the use of TCEs has to consider the community values, the origin of TCEs. ${ }^{37}$ In addition, Indonesian Copyright Law also regulates that the duration of protection of TCEs held by the state is unlimited. Based on the Explanation of Article 38 Indonesian Copyright Law, it can be understood that the subject matter of TCEs protection is in line with WIPO/GRTKF/1C/8/4. In these contexts, a question arises as to what is protected under TCEs or what is meant by traditional cultural expressions. The Explanation of Article 38 (1) Indonesian Copyright Law regulates those traditional cultural expressions, including any one or combination of forms of expression as follows:

a. verbal textual, both orally and in writing in the form of prose and poetry, in a variety of themes and content of the message content, which may be a literary work or an informative narrative

b. music, including among others, vocal, instrumental, or combinations thereof;

c. motion, covering, among others, the dance;

d. theaters, including among others, puppet shows and theatrical folk;

\footnotetext{
${ }^{37}$ See Article 38 (3) the Law No. 28 of 2014 concerning Indonesian Copyright.
} 
e. art, either in the form of two-dimensional or three the dimensions of which are made of various materials such as leather, wood, bamboo, metal, stone, ceramic, paper, textiles, etc. or combinations thereof; and

f. traditional ceremonies

Although Article 38 of the Indonesian Copyright Law has already regulated the protection of TCEs that may be appropriate as an embryo of the future Indonesia sui-generis TCEs, unfortunately "weaving" as one of the subject matters covered by expression of folklore that existed in the old Indonesian Copyright (the Law No. 19 of 2002) does not exist under new Indonesian Copyright Law. On the other hand, based on the Explanation of Article 10 (2) d. of the Law No. 19 of 2002, "traditional weaving" is clearly stated as part of the expression of folklore, particularly as part of works of art. Why it is very important to discuss the protection of 'traditional weaving' is due to the existence of traditional weaving that has developed, preserved, maintained, used as well safeguarded from generation to generation. It has some linkage with a community's social and cultural identity ${ }^{38}$ and cultural heritage. For example, the sacred traditional weaving in Bali used for tooth-filing ceremony known as "Sekordi Keling or in Jembrana Regency of Bali Province it is known as "Bikas Sekordi" usually with a simple motive that tends to be yellow in color as it pertains to social and cultural identity that is generally attributed to tooth-filing ceremony for teenagers. (Yellow color indicates that the teenagers are still virgin and unmarried). In addition, threemonth old children ceremonies and cremation ceremony related with community's social and cultural heritage use different motives of sacred traditional weaving, such as "Wangsul" motive developed in Buleleng Regency or "Rujak Boni" motive developed in Jembrana Regency for three and six-month old children ceremony. Meanwhile, Cepuk Ngawis motive developed in Nusa Penida,

\footnotetext{
${ }^{38}$ Cultural identity can be seen as the personification of culture. Comparable to culture, cultural identity is not static and homogeneous, but dynamic and heterogeneous. Aspects of cultural identity such as: art, language, religion, culture heritage ,traditions, customs, and institutions. See Yvonne M. Donders, 2002, Towards a Right to Cultural Identity, Intersentia, Oxford, New York, p.30.
} 
Klungkung Regency is used for cremation ceremony or also known as "Ngaben or Plebon ceremony."
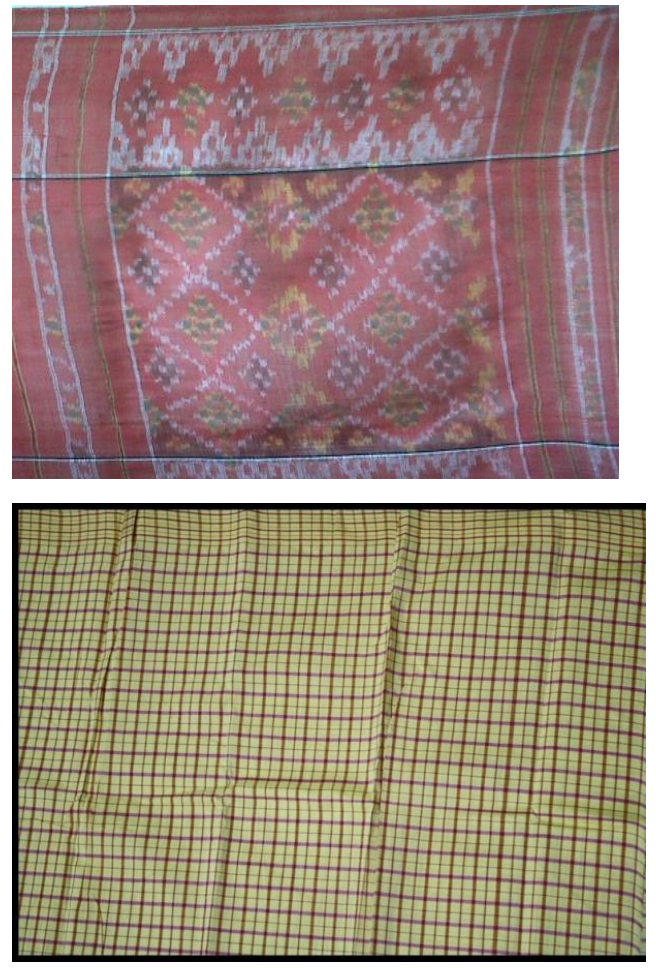

"Cepuk Ngawis"

Balinese sacred traditional weaving for Ngaben Ceremony

"Sekordi Keling"

Balinese sacred traditional weaving tooth-filing ceremony

By understanding that the existence of traditional weaving really takes an important role for the Balinese communities as mentioned above or may be also for other communities in Indonesia who have a similar social and cultural identity or sometimes associated with the belief and respect to ancestors, or for other purposes, then it is very important to mention the word "woven cloth" or "traditional weaving" as part of TCEs. Although based on the Explanation of Article 38 of the Law No. 28 of 2014, the protection of traditional weaving expression can be protected as part of "art" particularly the word "textile" or the word "etc." or may be by extending it can be covered by the element of the 
combination of traditional expressions so called "traditional ceremony", it still remains vague and too broad.

In general, the Indonesia Copyright Law is not adequate enough protecting Balinese traditional weaving, it can be seen through specific issues related with Copyright such as the scope of protection, ownership, and originality. As mentioned previously, related to the scope of protection, traditional weaving expressions do not exist as part of TCEs pursuant to both Article 38 and its Explanation. The issue of ownership is also difficult to determine precisely. The ownership or custodian it is still called into question, for example, how to determine ownership or holder of traditional weaving expression, particularly when communities among the other regency areas also develop and preserve traditional weaving expressions which are philosophically as well as social-culturally similar. The difficulty is not only tied to how to determine the ownership but more importantly, there is also still a debate concerning the precise term for the ownership discourse. There are various terms used to explain the holder such as indigenous communities, indigenous people, traditional communities, and cultural communities. The precise meanings of those terms are not clear. The terms indigenous and communities have very broad social and political concepts. ${ }^{39}$

The difficulty protecting Balinese traditional weaving is not only linked to substantive norms in order to protect more social values underpinning the traditional cultural expressions but also connected with law enforcement. The law enforcement becomes more at issue, particularly when traditional Balinese weaving is used for wider purposes that not only for cultural identity related to traditional ceremonies but also for daily clothing identity. In this context, the need for

\footnotetext{
39 Andrea Radonjanin, 2015, Folklor, Human Rights and Intellectual Property, Chapter 16, in Paul L.C. Torremans, 2015, Intellectual Property Law and Human Rights, Third Edition, Kluwer Law International, the Netherlands, P. 494.
} 
traditional weaving such as "woven endek" becomes increased. Indeed, since TRIPs Agreement has existed as one of the most comprehensive IP international conventions, the enforcement of Copyright, particularly protection for individual creative works has already indicated a change for the better including the law enforcement in Indonesia. However, the law enforcement of TCEs in accordance with the provision of Article 38 of Law No. 28 of 2014 still requires a more serious struggle. In practice, there are many TCEs have been illegally claimed and imitated by other parties who are not entitled to them. For instance, Balinese traditional weaving "Songket" and"Endek", were illegally imitated. The motives of Songket weaving from Jembrana regency, have been imitated by others who replace the base material with less expensive materials often found in clothing and textile stores. Thus, the products become less expensive, and consequently the Jembrana people who produce and preserve the Balinese traditional Songket weaving expressions become less competitive in the market. ${ }^{40}$

The infringement of the Balinese traditional weaving, including Songket, Endek, Cepuk, as well as Rang-Rang from Nusa Penida Bali is due to several factors, including the fact that the works have not been well-documented and systematically identified. Therefore, it is not easy to prove the ownership of such traditional cultural weaving as consequence of the legal aspect. The traditional Balinese woven motives lack identification as well as documentation; hence, it is difficult to prove the ownership rights of such works with regard to claimants and other parties. This can cause problems in the determination of the right holders both under communal and individual legal perspective. This is evident that is not easy to protect TCEs including traditional Balinese weaving as copyright because there is a lack of the important element of copyright concerning the "author" or "creator". Therefore, in order to protect traditional Balinese weaving as part of

\footnotetext{
40 Azhari, 2013, 'Mengangkat Tenun Songket Cagcag Jembrana' (Raising Songket Cagcag Woven of Jembrana Regency)', paper of the staff of the Department of Industry, Trade and Cooperative of the Jembrana Regency, the Province of Bali, p 1.
} 
TCEs, while waiting for the appropriate sui-generis law which is currently in Indonesia still in the form of bill, it does not seem only to rely on the copyright law as it is, but also it needs to use another regime of laws as comprehensive approaches, such as the use intangible cultural heritage as promoted by UNESCO as well as human rights approach. The relevant human rights regime to protect TCEs has greatly received attention from WIPO, more importantly, based on Article 31 United Nations Declaration on the Rights of Indigenous People. This declaration provides indigenous peoples with the right to maintain, control, protect and develop their intellectual property over such cultural heritage, traditional knowledge, and traditional cultural expression. The Declaration is frequently referred to in WIPO's work. ${ }^{41}$

WIPO IGC and Indonesian Copyright Law require identification and inventory for the traditional cultural expressions in order to protect TCEs. Documentation can be used as a defensive protection system. ${ }^{42}$ Therefore it is important to conduct the documentation and identification of Balinese traditional weaving as part of TCEs. By providing such TCEs documentation, it can be used to prevent cases of possession claims of the TCEs as previously happened in Indonesia. There were some cases concerning the expression of folklore or Traditional Cultural Expressions in Indonesia such as the Balinese traditional dance Pendet, the East Java traditional dance 'Reog Ponorogo' and the song "Rasa Sayange" which were claimed by unauthorized parties.

\footnotetext{
${ }^{41}$ WIPO, 2012, Intellectual Property and Genetic Resources, Traditional Knowledge and Traditional Cultural Expressions, World Intellectual Property Organization $\quad$ p. 6-7, http://www.wipo.int/edocs/pubdocs/en/tk/933/wipo pub 933.pdf.

${ }^{42}$ Agus Sardjono, 2006, Hak Kekayaan Intelektual Dan Pengetahuan Tradisional (Intellectual Property Right And Traditional Knowledge), Alumni, Bandung, p.284.
} 


\section{Protecting Traditional Balinese Weaving through Identifying and Inventorying Approaches}

Bali is a small beautiful island in Indonesia which is famous for its "Traditional Weaving" such as Endek, Songket, Cepuk as well as Rang - Rang as part of TCEs. The style and ornaments of these woven materials have existed since long time ago, passed down from one generation to another, conserved and sustainably developed by the Balinese people in various areas of Bali.

The development of traditional weaving in Bali began around the late 19th century, in which the Endek developed in many areas of Buleleng Regency. ${ }^{43}$ In the past, traditional weaving as mentioned previously was used for ritual purposes, particularly for royal families. In its development, to date, the traditional weaving cloth is not only used by the royal family for religious rituals but also used as everyday clothing by commoners. In addition, owing to economic improvement, more and more traditional weaving Endek are used. Although after Indonesia declared its independence in 1945, the manufacturing industry of the Balinese Endek grew rapidly in almost all regencies, in that period, the weaving looms called traditional "cag cag" have still been used to produce ended and songket. ${ }^{44}$

The creation or production of endek and songket has entered the commercial domain, which is not a traditional scope. Currently, its development is also for commercial exports. Responding to such development, it is important to realize the aspects of the legal protection of Balinese weaving expressions, especially when intended for commercial uses. It is expected that the Balinese weaving expression will not be claimed and used by outsiders who are not entitled to it; therefore, the

\footnotetext{
43 Supra note 2.

44 Ibid.
} 
inventorying effort as part of the documentation and the data collection of all types and varieties of Endek will greatly contribute to the legal protection of the TCEs.

As already mentioned above, the role of documentation and identification of traditionally woven Endek as part of TCEs serves as a piece of evidence to protect what needs to be protected, which in this case the uniqueness of the various Endek's motives spread in each regency in Bali, which later can be used to prevent a third party from using it wrongly or inappropriately. A documentation model can be developed in order to preserve, safeguard, as well as protect TCEs including Balinese traditional weaving by documenting the name of traditional weaving expression, the philosophy underlining the characteristic, function, briefs history, custodian, current condition, effort to preserve, cultural maestro as well as the documentation related to them. One example of the model documentation of traditional Balinese weaving is as follows ${ }^{45}$ :

Traditional Weaving Endek Jembrana of Bali Province

1.Number and Registration Code: In 2013, Number: 00001

2.Group of the Traditional Cultural Expression: Traditional Textiles of Bali

3.Name of the Traditional Cultural Expression: Tenun Endek Jembrana (Traditional Endek Jembrana)

4.The owner (Custodian): Balinese communities in Jembrana Bali Province who preserve, safeguard, maintain, develop, use and protect it.

5.Name of Person or Social Group who gave the information:

Dewa Kariasa, the vice village chief of Sangkar Agung,the Regency of Jembrana, Bapak Azhari, the chief of IKRT (Household Creative Industries) also a staff of the Department of Industry,Trade and Cooperative of the Jembrana Regency, Ibu Ristina, a staff of the Department of Industry,Trade and Cooperative of the Jembrana Regency, Ibu Nengah Metri, a weaver and the owner of Endek weaving company of Amerta Yasa, Manis Tutu, Jembrana, Ibu Ketut Suparti, a weaver and the owner of Endek weaving Meka Sari Dusun Dauh Waru, Jembrana,Ibu

\footnotetext{
45 Ni Ketut Supasti Dharmawan, et al, 2013, Identifikasi Karya Tenun Tradisional Bali Dalam dimensi perlindungan Hak kekayaan Intelektual (The Identification of Balinese Traditional Weaving) in Intellectual Property Rights Dimension, Aneka Ilmu, Semarang, p. 41-47.
} 
Dharma, a weaver and the owner of Endek and Songket weaving UD Sekar Ngoneng, Banjar Ngoneng Mendoyo Dauh Tukad Jembrana

6.Approval of the Recording of the Traditional works/Cultural Works:

It is important of documenting and publicizing the Balinese traditional Endek Weaving in Jembrana, for the purpose of proof of ownership (custodian) and the availability of data on the existence and the ownership of Traditional Balinese Endek Weaving developed in Jembrana Bali.

7. A Brief History of Traditional Cultural Expressions:

The weaving Endek Jembrana passed_on for generations and developed in Jembrana are the same as that from other regencies where they have existed for a long time. Even during the Dutch colonial era, the traditional cultural expressions of Endek already existed in Jembrana. At first, the traditional woven fabrics were made for the needs of traditional ceremonies in Bali and were commonly used by both men and women as Kamben wastra for clothing or traditional ceremonies and prayers at the temple. Endek woven fabric is generally made or woven by the housewives. Besides for the needs of customs and religious ceremonies, the Endek cultural weaving is now usually produced for clothing, generally for office uniforms. Jembrana has recently introduced a certain motive of Endek called "Endek Makepung" which is used as a uniform for Jembrana Government officers. This was inspired by the characteristic or icon of Jembrana Regency which is well known for its bull racing or Makepung cultural arts festival. The existence of Endek weaving in Jembrana, especially in the village of Dauh Waru and Manis Tutu is an activity that has been cultivated for generations by the housewives. It is a source of livelihood for the families who have inherited the weaving skills from the older generation. Endek weaving activities are also growing in the village of Mendoyo Dauh Tukad is developed by a group of Sekar Ngoneng and Saka Kembang. Currently, the Government of Jembrana is developing a Technical Guidance Program for housewives to continue the traditional Endek weaving activities by using manual looms.

8. Typical Characteristics and uniqueness of Traditional Work /Cultural Works:

The Balinese Jembrana Endek weaving that developed in the community of Jembrana is almost the same as in other regencies, the motives are taken from the decorative "Reringgitan Lontar" reflecting religious ceremonies in the Hindu community of Bali, as well as the Balinese typical folklore motives inspired by flora and fauna, for instance, the motives of plants such as Kangkung motifs/ Watercress motives and Bun-Bunan motive/ the vine motives, and the presence of animals known as motives of "Merak-Merakan/ peacocks". Another distinctive feature of Jembrana Endek woven fabric is that they weave generally the same 
motives as typical Songket weaving of Negara (Jembrana) such as the motive of "Cerari". Today, one of the special and unique features, very well-known in Traditional Woven Cloth of Endek, derived from Jembrana Regency, is called Endek "Mekepung motive". It certainly cannot be found in other regencies in Bali, because Mekepung is derived from the traditional culture of Mekepung (a bull race performed in the rice fields as an icon of Jembrana Regency). Endek in Jembrana is made by using Metris or Rayon yarn woven by manual looms.

9.The function and the philosophical Meaning of Traditional Cultural Expressions:

The function of Endek weaving was originally intended for custom clothing (Wastra or Kamben) for both men and women as well as for traditional clothes for praying at the temple. Specifically little is known about the philosophical meaning of the traditional Endek woven cloth, the artisans or designers just said that they only follow the previous motives passed down from generation to generation, because many motives are associated with "Reringgitan Lontar" ceremony, the meaning could be uniting holiness of heart in the implementation of traditional ceremonies by wearing traditional Endek. Besides the existence of plants as decorative motives for Endek woven materials, its philosophy and meaning can be stated as a realization of harmony with the natural environment whereas the philosophy and the meaning of Endek developed in Jembrana, namely the Mekepung motives, are the togetherness and the spirit of persistence in conducting a variety of jobs, to always work hard and never give up. The philosophy of Balinese people with values of harmony and togetherness known as the spirit of Bali Tri Hita Karana. ${ }^{46}$ The original phrase of Tri Hita Karana comes from Sanskrit words: Tri (three), Hita (prosperity), Karana (cause). This philosophy signifies three causes of prosperity produced by balanced and harmonious relations in one whole unity between human and God; human and society; human and nature. ${ }^{47}$ The spirit and values of Tri Hita Karana embodied in various motives of Balinese woven materials such as Endek Bun-Bunan motives (the art of wild flora) and Endek KapuKapu motives (the leaves of floating water plant) that show the balance and harmony of the relationship between human and environment, human and human, human and God.

10. Supporting Community/Community Name/Social Organization:

Communities pursue and develop in a sustainable manner as well as observers of the Endek woven fabrics in Jembrana include:Ibu Ketut

\footnotetext{
${ }^{46}$ Jan Hendrik Peters and Wisnu Wardana, Discovering the Spirit of Bali in Michael Gerbert Faure et.al., Sustainable Tourism and Law, (Eleven International Publishing, The Hague, 2014), p 25.

47 Jan Hendrik Peters \& Wisnu Wardana, 2013, Tri Hita Karana the Spirit of Bali, Kepustakaan Popular Gramedia, Jakarta, Indonesia,, p.40-41.
} 
Suparti, name of group : Mekar Sari, Area of Dauh Waru, Menega, Subdistrict of Jembrana the Regency of Jembrana, Ibu Nengah Metri, name of group: Amerta Yase, Village of Manis Tutu, Ketut Mardiana, MPP from the Department of Industry and Trade, an instructor of the Technical Guidance, Ibu Dharma, of Sekar Ngoneng, The Department of Industry, Trade and Cooperative of Jembrana Regency, through the development of several sustainable Technical Guidance in order to develop the traditional Balinese textiles of Endek in Jembrana.

11. Cultural Master/Maestro:

Based on interviews in several communities who focus on Endek weaving tradition, there is an example of some people who have the skill to weave such as Ibu Ketut Suparti, Ibu Nengah Metri, Ibu Dharma.

They do not actually want to be called 'Master' or 'Maestro'; they are only people who continue their profession to make Endek in the Regency of Jembrana and to hand it down to the next generation and encourage community members to work on preserving the tradition of weaving Endek fabrics in Jembrana.

12. The locations of Traditional Works/Cultural Works:

Village of Manis Tutu the Regency of Jembrana, Area of Dauh Waru, Area of Dauh Waru, Menega, Sub-district of Jembrana the Regency of Jembrana, Banjar Ngoneng, Mendoyo Dauh Tukad, Regency of Jembrana, Loloan Barat and Loloan Timur, Regency of Jembrana,

13. The current condition of Traditional Works/Cultural Works:

Until now, the expression of Endek of Jembrana continues to grow, not only for the needs in Jembrana, but they are also marketed in Denpasar. Endek weaving is used for the traditional Wastra or Kamben (cloth go to the Temple for religious purposes) as well as for clothing and has lately begun to be marketed outside Bali.

14. Efforts of Preservation/Promotion:

In Jembrana Regency, efforts have been made to preserve the existence of traditional Ikat Weaving including the formation of groups and activities organized by the Department of Technical Guidance of The Department of Industry, Trade, and Cooperative of Jembrana Regency. The technical guidance activities carried out starting from the most basic activities in the process of weaving cloth traditionally.

15. The Documentation of the Traditional works:

Efforts of documentation are used as a proof of ownership and legal certainty in the field of protection of the Traditional Folklore of Endek Woven fabrics are affected by documentation books. Other books include:

- The tracer study team of the Balinese Traditional Intellectual Property that potentially has the Intelectual Property Rights, 2010, Penelusuran Kain Songket Bali /Tracing the Balinese Songket Woven Fabrics, a 
cooperation between the Ministry of Culture and Tourism of Indonesia with Udayana University.

- Schaublin and Ramseyer, 1991, Textiles in Bali, Periplus EditionBerkeley-Singapore, or

- Through Websites: some websites start informing about the existence of the Balinese Endek including Endek of Jembrana

16. Photo of Documentation / Illustration:

Photo documentation of the results of identification of the traditional woven cloth of Balinese Endek, growing in Jembrana is as follows:

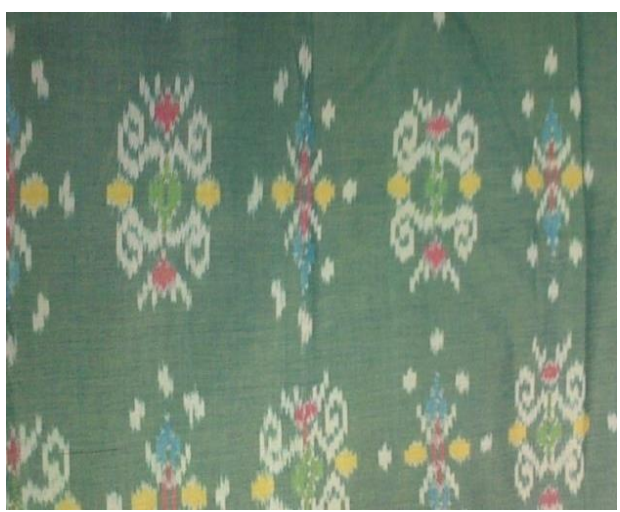

Endek traditional weaving with motif of : Geringsingan, developed in Jembrana by Mekar Sari, Dauh Waru

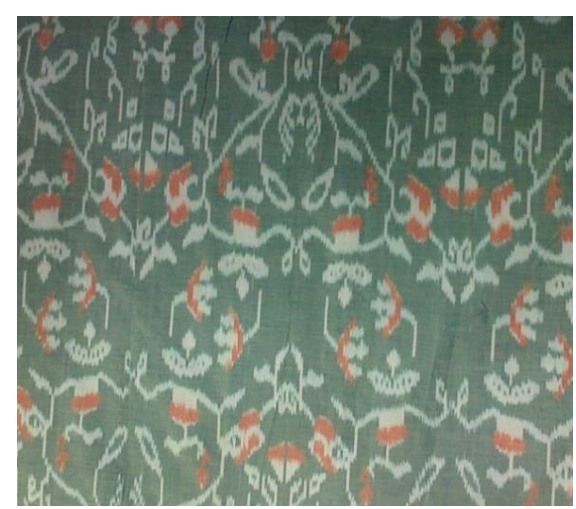

Endek traditional weaving with motif of: Kangkung, developed in Jembrana by Mekar Sari, Dauh Waru 

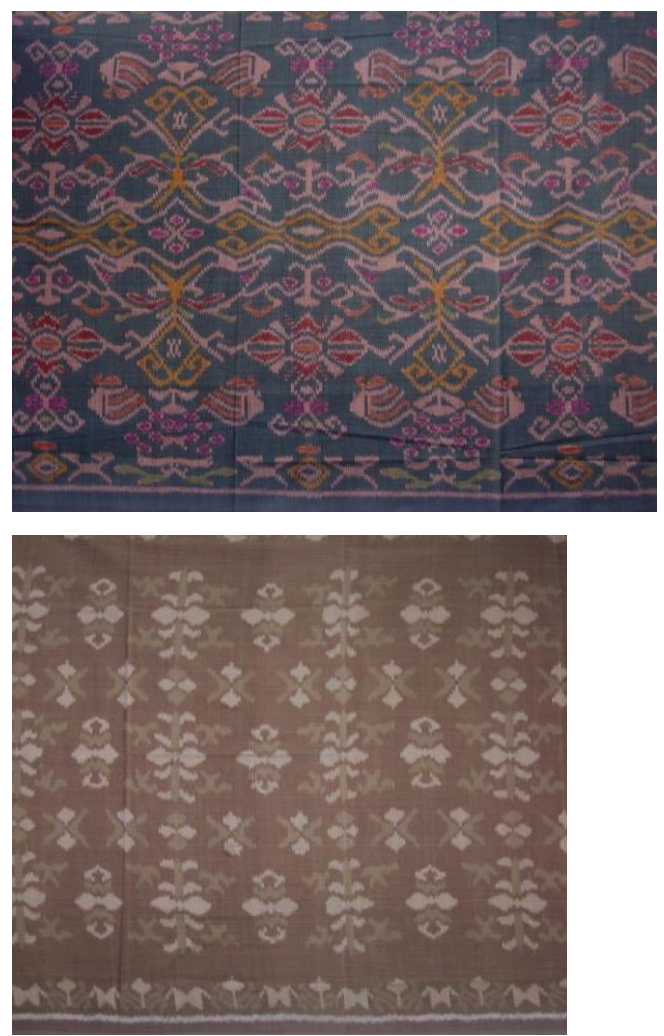

Traditional Endek weaving with motive of Traditional Endek weaving with motive of Kapu Kapu orti ornament (taking a cutting shape of palm (leaves of floating water plant) developed in Jembrana leaf manuscript for ritual purposes in Bali one of them by Ngoneng Group. developed in Jembrana one of them by Ngoneng Group

\section{Conclusion}

It can be concluded that Copyright Law itself is not appropriate enough to protect TCEs including traditional Balinese weaving. Therefore, to preserve, safeguard, maintain as well as to protect it comprehensively, TCEs, as well as the traditional Balinese weaving, need to rely on another regime of laws such as intangible cultural heritage, sui-gneris model provisions related to intellectual property, as well as human rights approach. While waiting for sui generis model provisions proposed by WIPO IGC, internationally as well as the Indonesian Bill of TCEs enacted as the Law, it is relevant to apply the Indonesian Copyright Law accompanied by other regime of laws such as human rights law connected to the 
right to culture and Indigenous Rights as stipulated under various Human Rights Conventions, as well as Customary Law that exist in the community of TCEs. Further, it is also important to provide inventory model of TCE including the traditional Balinese weaving. The important role of this document provides legal certainty of the holder/ownership/custodian of the weaving expressions. Through this Model of Documentation, various motives of traditional weaving can be identified and documented which are passed down from generation to generation, created and preserved by the Balinese communities. This significance and philosophy underline the expression motives of Balinese weaving such as BunBunan, Pepatraan, Pengiringsingan, Flower, Birds, Grapes Leaves and other natural motives around the environment which can be perceived and recognized where they are very much related to the expression of gratitude to God the Almighty, harmony with the surrounding nature (flora and fauna) which is the manifestation of the Tri Hita Karana principle. The traditional Balinese weaving exists as part of the social cultural identity of their community.

As a recommendation, it is expected that the documentation of the existence of the Traditional Balinese weaving should be continuously carried out by the relevant institutions, universities, and other stakeholders with regard to the certainty of the legal protection. In addition, the protection and preservation of TCEs can be effected by constructing a legal basis in the form of the Local Government Regulation.

\section{References}

Agus Sardjono, 2006, Hak Kekayaan Intelektual Dan Pengetahuan Traditional (Intellectual Property Right And Traditional Knowledge), Alumni, Bandung Alpana Roy, 2008, 'Intellectual Property Rights: A Western Tale', (2008) 16 Asia Pac. L. Rev. at 222

Andrea Radonjanin, 2015, Folklore, Human Rights and Intellectual Property, Chapter 16, in Paul L.C. Torremans, 2015, Intellectual Property Law and Human Rights, Third Edition, Kluwer Law International, the Netherlands 
Azhari, 2013, 'Mengangkat Tenun Songket Cagcag Jembrana' (Raising Songket Cagcag Woven of Jembrana Regency)', paper of the staff of the Department of Industry, Trade and Cooperative of the Jembrana Regency, the Province of Bali

Christoph B. Graber, Karolina Kuprecht and Jessica C. Lai (Eds.), 2012, International Trade in Indigenous Cultural Heritage: Legal and Policy Issues, Edward Elgar Publishing Limited, Cheltenham

Enyinna Sodienye Nwauche, 2010, Protecting Expression of Folklore Within the Right to Culture in Africa, PER/PELJ 2010 (13)4, Paper Presentation at Conference on Traditional Knowledge in Legal Context, the Potchefstroom Campus of the Northwest University South Africa

F Scott Kieff-Ralph Nack, International, United States and European Intellectual PropertySelected Source Materials (Aspen Publisher, New York, 2008)

Federico Lenzerini, 2011, Intangible Cultural Heritage: The Living Culture of Peoples, The European Journal of International Law (EJIL) (2011), Vol. 22 No. 1

Hee-Eun Kim, 2011, Changing Climate, Changing Culture: Adding the Climate Change Dimension to the Protection of Intangible Culture Heritage, International of Cultural Property, 18-259-290, doi:10.1017/S094073911100021X, Printed in USA

International Cultural Property Society, 2005, Regional Framework for the Protection of Traditional Knowledge and Expression of Culture, Secretariat of the Pacific Community: Model Law for the Protection of Traditional Knowledge and Expressions of Culture, International Journal of Cultural Property, 12:459-465, DOI: 10.1017/S0940739105050290, Printed in the USA

Jamie Crook, 'Balancing Intellectual Property Protection with the Human Right to Health' (2005) 23 Berkeley Journal of International Law 524 at 530, http: //scholarship.law.berkeley.edu/bjil/vol23/iss3/I, accessed 26 April 2014 Jan Hendrik Peters and Wisnu Wardana, 2013, Tri Hita Karana the Spirit of Bali, Kepustakaan Popular Gramedia, Jakarta, Indonesia

Jan Hendrik Peters and Wisnu Wardana, Discovering the Spirit of Bali in Michael Gerbert Faure et.al., Sustainable Tourism and Law, (Eleven International Publishing, The Hague, 2014)

Jo Recht, 2009, Hearing Indigenous Voices, Protecting Indigenous Knowledge, International Journal of Cultural Property, 16-223-254, DOI:10.1017/S0940739109990166, USA 
Jordanna Bowman, 2011, Coping with Culture: Copyright, cultural expressions and inadequacy of protection for Maori, University of Otago, Dunedin, New Zealand

Martin Girsberger and Benny Muller, 2012, International Trade in Indigenous Cultural Heritage : an Practitioners' Perspective, in Christoph B. Karolina Kuprecht and Jessica C. Lai, 2012, International Trade in Indigenous Cultural Heritage Legal and Policy Issues, Edward Elgar, UK

Michael Blakeney, 2015, Protecting The Knowledge and Cultural Expressions of Aboriginal Peoples, University of Western Australia Law Review, Volume 39 (2), ISSN 0042-0328

Ni Ketut Supasti Dharmawan, et al, 2013, Identifikasi Karya Tenun Tradisional Bali Dalam dimensi perlindungan Hak kekayaan Intelektual ( The Identification of Balinese Traditional Weaving) in Intellectual Property Rights Dimension, Aneka Ilmu, Semarang

Schaublin and Ramseyer, 1991, Textiles in Bali (Periplus Edition-BerkeleySingapore,

William Cornish and David Llewellyn, 2003, Intellectual property: Patents, Copyright, Trade Marks and Allied Rights, Sweet \& Maxwell, London.

WIPO Booklet on Intellectual Property and Genetic Resources, Traditional Knowledge and Traditional Cultural Expression

WIPO,2016, No.2 WIPO Intergovernmental Committee on Intellectual Property and Genetic Resources, Traditional Knowledge and Folklore, Geneva 20, Switzerland

Yvonne M. Donders, 2002, Towards a Right to Cultural Identity, Intersentia, Oxford, New York

WIPO, Traditional Cultural Expression, http://www.wipo.int/tk/en/folklore/

OHCHR, 1996-2016, UNESCO Universal Declaration on Cultural Diversity (2001), adopted by The General Conference, Paris, France, 2 November 2001 , http://www.ohchr.org/EN/Issues/Education/Training/Compilation/Pages/19 UNESCOUniversalDeclarationonCulturalDiversity(2001).aspx,

UNESCO, 2016, The Convention for the Safeguarding of Intangible Cultural Heritage, http://www.unesco.org/new/en/santiago/culture/intangibleheritage/convention-intangible-cultural-heritage/.

The International Bureau of WIPO, 1998, The Protection of Expression of Folklore: The Attempts at International Level, Intellectual Property in Asia and the Pacific, No. 56/57 [ISSN 1014-336X, WIPO Publication No. 435(E)] http://www.dsir.gov.in/pubs/itt/itt9903/folklore.htm 
WIPO/GRTKF/1C/8/4, 2005, Intergovernmental Committee on Intellectual Property and Genetic Resources, Traditional Knowledge and Folklore, Eighth Session, June 6 to 10, Geneva

WIPO, Traditional Knowledge and Intellectual Property-Background Brief, http://www.wipo.int/pressroom/en/briefs/tk_ip.html, accessed 1 September 2016

WIPO Booklet No. 1, Intellectual Property and Traditional Cultural Expression / Folklore, WIPO Publication No. 913 (E), ISBN 978-92-805-1363-9, p. 5. , http://www.wipo.int/edocs/pubdocs/en/tk/913/wipo_pub_913.pdf.

WIPO, 2012, Intellectual Property and Genetic Resources, Traditional Knowledge and Traditional Cultural Expressions, World Intellectual Property Organization, http://www.wipo.int/edocs/pubdocs/en/tk/933/wipo_pub_933.pdf.

Doha Ministerial Conference, 2001, Fourth Session, 9-14 November 2001, ,http://www.wto.org/english/thewto_e/minist_e/min01_e/mindecl_e.doc

TRIPs Agreement

The Law No. 28 of 2014 concerning Indonesian Copyright.

Universal Declaration of Human Rights 1948

International Covenant Civil and Political Rights

International Covenant Economic Social and Cultural Rights

United Nations Declaration on the Rights of Indigenous People 